\title{
Review
}

\section{Huntingtin: Here, There, Everywhere!}

\author{
Cristovao Marques Sousa and Sandrine Humbert* \\ Institut Curie, CNRS UMR 3306, INSERM U1005, Orsay, France
}

\begin{abstract}
Huntingtin is the protein mutated in Huntington disease, a dominant inherited neurodegenerative disorder. Huntingtin is ubiquitously expressed throughout the body, however its role outside the central nervous system has been overlooked. This review focuses on the peripheral distribution of huntingtin. It also highlights that huntingtin has central cellular functions, the importance of which may extend beyond the nervous system. Because of the breadth of huntingtin expression and functions, mutant huntingtin undoubtedly causes peripheral disturbances and may be involved in other non neuronal pathologies.
\end{abstract}

Keywords: Huntingtin, peripheral tissues, expression pattern, huntingtin function

Huntington disease (HD) is an autosomal dominant inherited neurodegenerative disorder [1]. The most characteristic symptoms of HD are psychiatric disorders, cognitive decline and disturbance of muscle coordination. The signs and symptoms of the disease generally emerge during mid-adulthood. The mutation causing $\mathrm{HD}$ is an abnormal CAG expansion in the IT15 (HTT) gene coding for the protein huntingtin (HTT) [2]. The expanded CAG repeat encodes a polyglutamine stretch near the $\mathrm{N}$-terminus of the protein, and its size correlates with the time of onset of the disease: particularly large expansions are linked to juvenile forms of the disease [3]. The major histological feature of the disease is massive neuronal loss. Selective death of neurons in the striatum and cortex regions is particularly marked. Thus, in view of the neurological signs, the neuropathology and the dominant trait of $\mathrm{HD}$, research on this disease has historically focused on the dominant gain of toxic function of mutant HTT in post-mitotic neurons. However, evidence is now emerging that other issues need to be considered if we are to understand the progression of HD.

\footnotetext{
*Correspondence to: Sandrine Humbert, PhD, Institut Curie, CNRS UMR 3306, INSERM U1005, Orsay, F-91405, France. Tel.: +331698630 69; E-mail: sandrine.humbert@curie.fr.
}

\section{HTT EXPRESSION IS NOT RESTRICTED TO THE BRAIN}

HTT expression is ubiquitous (Table 1), as established shortly after the identification of the gene in 1993 [2]. Northern blot analyses and in situ hybridization have shown the presence of human HTT transcripts throughout the brain and also in heart, placenta, lung, liver, muscle, kidney, pancreas and testes [4, 5]. By 1995, with the development of specific antibodies, the HTT protein had been found both in the brain and also elsewhere than the central nervous system [6-8]. Since then, studies have shown that human HTT is present in several non central nervous system-derived cells $[6,7$, 9-17]. Similarly, rat and mouse HTT are found at various concentrations throughout most tissues $[4,7,8,14$, 17-22]. The wide distribution pattern of HTT is confirmed by studies analyzing HD mouse models where HTT is expressed under its own promoter. In these models, mutant HTT is observed in different peripheral tissues where it forms intranuclear inclusions [23-26].

However, a thorough and careful analysis of HTT expression is still required. Indeed, most relevant studies report the presence of the protein in lysates of whole tissues: the abundance of HTT has not been systematically evaluated in the diverse cellular subtypes 
Table 1

A summary of the litterature on HTT peripheral expression

\begin{tabular}{|c|c|c|c|c|}
\hline HTT & Species & Cells, tissues & Method & Reference \\
\hline WT and mutant & human & monocytes & RT-PCR & [9] \\
\hline WT and mutant & human & lymphoblasts & PCR & [10] \\
\hline WT and mutant & human & lymphoblasts & $\mathrm{WB}, \mathrm{IF}$ & {$[6,7,10-15]$} \\
\hline WT and mutant & human & primary muscle cell cultures & IF & [16] \\
\hline WT and mutant & human & heart, testis, kidney, lung, liver & WB & {$[6,8]$} \\
\hline WT and mutant & human & mammary tissue, breast tumors & IHC & {$[22]$} \\
\hline WT & human & $\begin{array}{l}\text { heart, placenta, lung, liver, skeletal } \\
\text { muscle, kidney, pancreas }\end{array}$ & Northern blot & [4] \\
\hline WT & human & $\begin{array}{l}\text { pancreas (acini, ducts, islets of } \\
\text { Langerhans, connective tissue), } \\
\text { testis (spermatogonia, primary } \\
\text { spermatocytes) }\end{array}$ & in situ hybridization & [5] \\
\hline WT & human & skin fibroblasts & IF, WB & [17] \\
\hline WT & rat & $\begin{array}{l}\text { testis, ovary, lung, spleen, liver, heart, } \\
\text { kidney, small intestine }\end{array}$ & Northern blot & {$[4,18]$} \\
\hline WT & rat & testis, liver, spleen, kidney & WB & {$[7,14]$} \\
\hline WT & mouse & $\begin{array}{l}\text { embryonic liver, lung, kidney, heart, } \\
\text { and adult liver, lung, placenta }\end{array}$ & Northern blot & {$[18,19]$} \\
\hline WT & mouse & $\begin{array}{l}\text { embryonic liver and heart, adult testis } \\
\text { (expression limited to meiotic } \\
\text { cells, spermatocytes I and II) }\end{array}$ & in situ hybridization & [18] \\
\hline WT & mouse & $\begin{array}{l}\text { embryonic liver, hematopoietic cells, } \\
\text { adult bone marrow }\end{array}$ & RT-PCR & [20] \\
\hline WT & mouse & $\begin{array}{l}\text { heart, kidney, testis, liver, lung, } \\
\text { muscle, spleen, lymph node, } \\
\text { hematopoietic cells, mammary } \\
\text { cells }\end{array}$ & WB & {$[8,20,21][22]$} \\
\hline WT & mouse & embryonic fibroblasts & IF & [17] \\
\hline
\end{tabular}

RT-PCR: reverse transcription-PCR; WB: western blot; IF: immunocytofluorescence; IHC: immunohistochemistry.

within peripheral tissues. A low level of HTT in a tissue sample may reflect the heterogeneity of HTT production: it may be abundant in some cellular subtypes and absent from others. Also, the precise subcellular distribution of HTT in peripheral cells is not available. We explored HTT distribution in a comprehensive array of normal human tissues using the freely available Human Protein Atlas web-based database (http://www.proteinatlas.org/ENSG00000197386, ver sion 10.0) [27]. An analysis of HTT in several normal human tissues with two antibodies targeting different regions of HTT (MAB2166, Ab1, Chemicon and HPA026114, Ab2, Sigma-Aldrich) reveals moderate to high levels of the protein in many tissues (Fig. 1). As expected, HTT is abundant in several regions of the brain and various cell types in the central nervous system. For example, both neurons and glial cells in the cortex are stained, with higher levels of HTT in neurons (Fig. 1). HTT is also found in other cell types and tissues including: hematopoietic cells (bone marrow, white and red pulp in the spleen), glandular epithelium (fallopian tube, colon, breast, salivary gland, pancreas, and uterus), squamous epithelium (skin), macrophages and pneumocites in the lung, seminiferous ducts in the testis and glomeruli or tubule cells in the kidney. All these tissues express moderate to high levels of HTT. One striking observation is that cells with little or no HTT are mesenchymal cells. Indeed, the antibodies do not label, or only weakly label, fibroblasts in skin, adipocytes in breast, stromal cells in uterus, myocytes and smooth muscle cells, all these cell types share mesenchymal properties. Interestingly, epithelial cells in the same tissues as these mesenchymal cells have higher levels of HTT as illustrated by the high expression observed in the ductal cells in the mammary gland and squamous epithelial cells in the skin. This distribution of HTT, present mostly in epithelial cells, is in agreement with recent studies indicating that HTT is a regulator of tissue maintenance and cell morphology. Mammary tumor cells that express mutant HTT undergo more substantial epithelial-to-mesenchymal processes than cells with the wild-type HTT [22]. This may be the result of the expression of the mutant form of HTT, or alternatively due to the underexpression of the wild-type HTT: tumors expressing the mutant HTT contain less wild-type HTT. Consistent with this, reducing HTT levels in zebrafish embryos impairs $\mathrm{N}$-cadherin-mediated adhesion and leads to aberrant distribution of the tight junction protein zona occludens 1, ZO1 [28]. The mRNAs for adherence proteins are 
also less abundant in embryonic stem cells and neurons with lowered HTT levels than controls [29].

HTT has a wide distribution at the subcellular level. It is found in the nucleus and in the cytoplasm, within neurites and at synapses [6, 30]. It associates with various organelles and structures, including clathrin-coated vesicles, endosomal and endoplasmic compartments, mitochondria, microtubules and the plasma membrane [14, 31-34].

Thus, HTT has a broad expression pattern at the histological, cellular and intracellular levels. However, this does not mean that the distribution of HTT is homogeneous in space and time. The amount of HTT differs between cell types within a tissue (see above), and HTT is expressed from early development to adulthood. The expression profile of HTT thus raises questions concerning the functions of HTT in these tissues, the relevance of these functions to tissue homeostasis, and the consequences of dysfunctions of HTT in the context of HD.

\section{HTT FUNCTIONS}

HTT has been implicated in a large range of cellular events during development and adulthood, mostly in the nervous system. HTT is required for normal embryogenesis, as knock-out mice for HTT die at an early developmental stage, embryonic day 7.5 [35-37]. In adult mice, ablation of HTT in the forebrain and in the testes leads to neurodegeneration and sterility [38]. HTT is involved in neurogenesis during both development and adulthood $[39,40]$. It also participates in the control of neuronal synaptic activity [41]. How can HTT participate in such a variety of physiological processes? It is possible that the effects of HTT at the tissue level may be the consequence of a limited set of functions at the molecular level. Indeed, a common point to the physiological functions of HTT is that they may often be related to the role of HTT as a regulator of transcription and of intracellular dynamics.

HTT shuttles between the cytoplasm and the nucleus [42]. Its sequence contains two nuclear export signal sequences (NES), a karyopherin $\beta 1 / \beta 2$ prolinetyrosine nuclear localization signal (NLS), and polyQ and polyP sequences that form polar zipper structures and interact with DNA [43-46]. HTT interacts with several transcription factors including the cAMPresponse element-binding protein (CREB binding protein, CBP) [47], the specificity protein-1 (SP1) [48], the nuclear factor-kB (NF-kB) [49] and the tumor suppressor protein 53 (p53) [47]. HTT also interacts with transcriptional repressors: the nuclear co-repressor (NCOR) [50], the repressor element-1 transcription factor/neuron restrictive silencer factor (REST/NRSF) [51] and the transcriptional corepressor C-terminal-binding protein (CtBP) [52]. Through these interactions, HTT can potentiate transcription factors and inhibit repressors (and vice-versa) and thereby promote and repress gene transcription. For instance, p53 interacts with HTT $[47,53]$, thus blocking the transcription of p53 target genes including the multi-drug resistance gene (MDR1). The HTTdependent p53 transcriptional regulation depends on the polyQ and polyP expansions in HTT. As p53 positively regulates the transcription of genes involved in cell cycle control, apoptosis, cellular stress response and DNA repair, the interaction of HTT with p53 may be a mechanism by which HTT regulates a wide range of cellular outcomes. In line with this idea, HTT activates the transcription of genes containing a conserved 21-23 base pair DNA Repressor element 1 sequence (RE1 also known as the neuron-restrictive silencer element, NRSE) [51]. This sequence is recognized by the RE1-silencing transcription factor (REST; also known as neuronal restrictive silencing factor, NRSF), a transcriptional regulator which acts as a transcriptional silencer. HTT may thus act as a positive transcriptional regulator for these genes [51]. An example is the brain-derived neurotrophic factor (BDNF) gene, the promoter II of which contains a NRSE. Wildtype HTT promotes $B D N F$ transcription through the sequestration of the available REST/NRSF in the cytoplasm, thereby preventing it from forming the nuclear co-repressor complex at the RE1/NRSE nuclear site.

Although HTT is present in the nucleus, the protein is mostly in the cytoplasm where it associates with vesicles and microtubules. HTT is indeed crucial for vesicular trafficking with consequences for axonal transport and endocytosis. In the same way as for its transcriptional function, the role of HTT in these trafficking and transport processes is supported by the nature of its interactors. HTT binds dynein and HAP1 directly [54], and kinesin [55] and the dynactin subunit p150 Glued [56] indirectly. HTT is a facilitator of the transport of several cargoes along microtubules [33, 57, 58]. Reducing HTT levels leads to a decrease in both anterograde and retrograde transport of BDNF and its receptor TrkB $[33,59]$. HTT is also required for the transport of proteins to the centrosome [39] and to the base of the cilia [60]. The action of HTT in microtubule-based transport is regulated by phosphorylations at serine 421 (S421; [61]) and serines 1181 and 1201 (S1181/S1201; [40]). In particular, phosphorylation of HTT at S421 favors the interaction between 


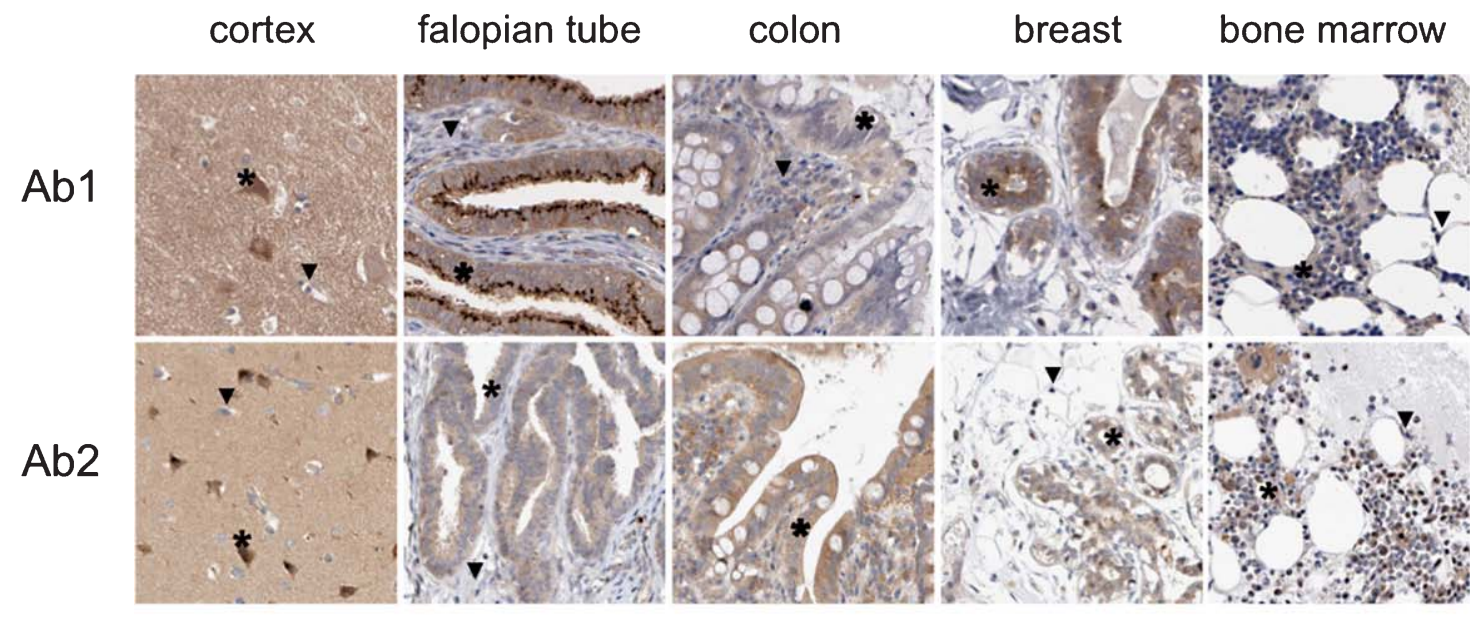
salivary gland
pancreas
lung
kidney
heart

$\mathrm{Ab} 1$
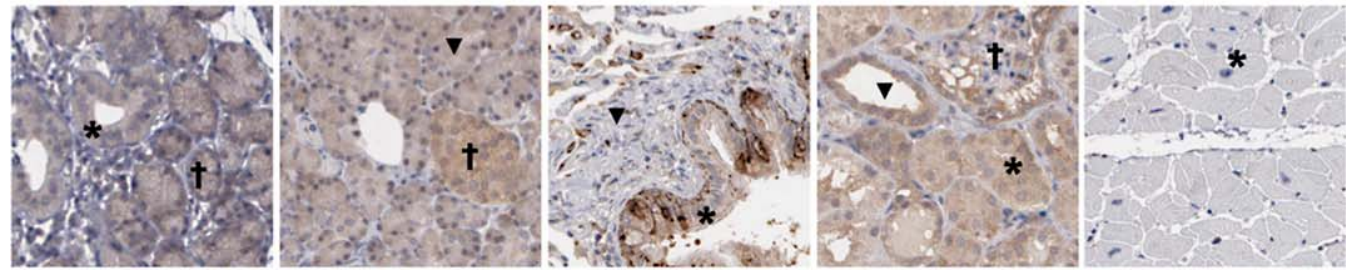

$\mathrm{Ab} 2$
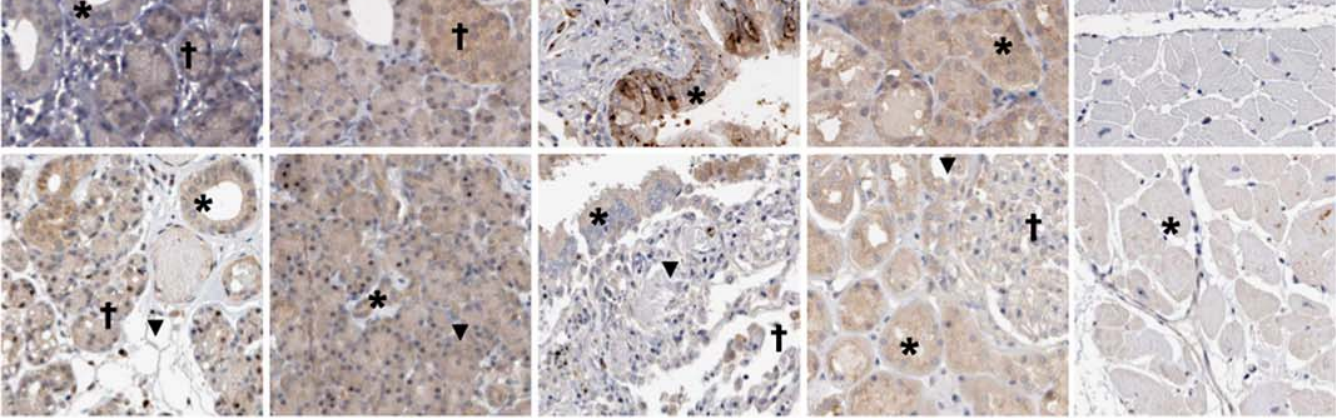

$\mathrm{Ab} 1$

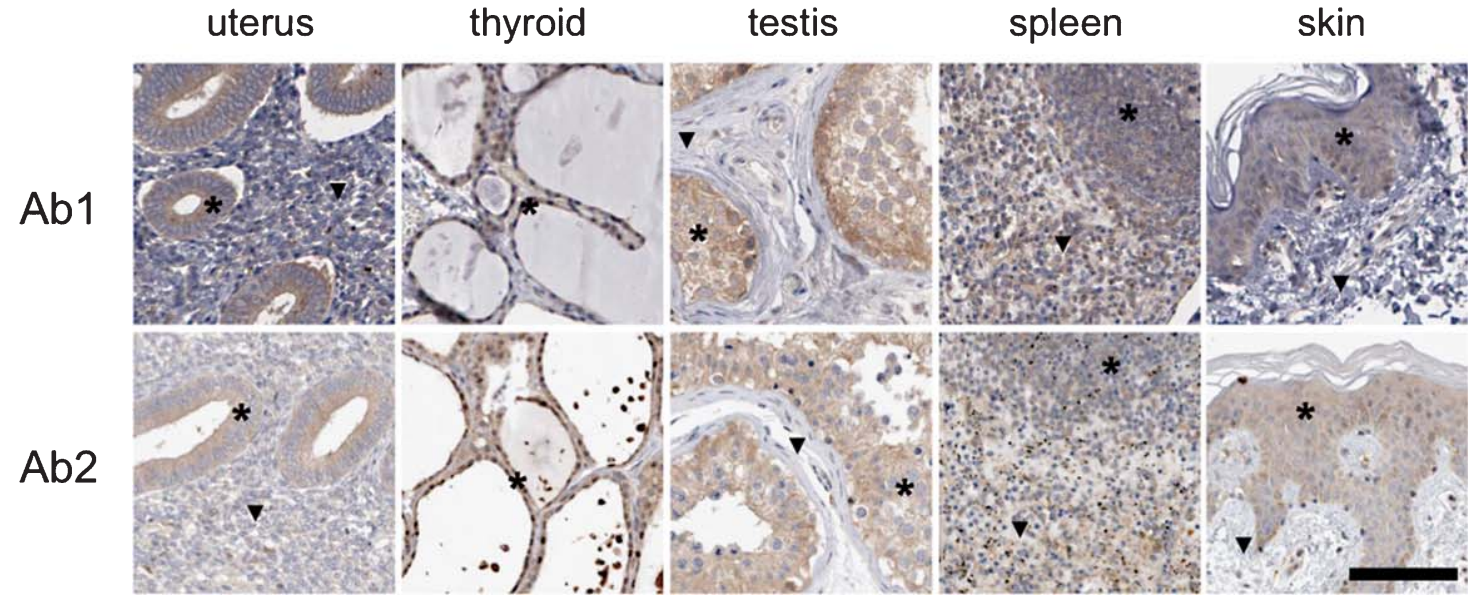

thyroid

testis

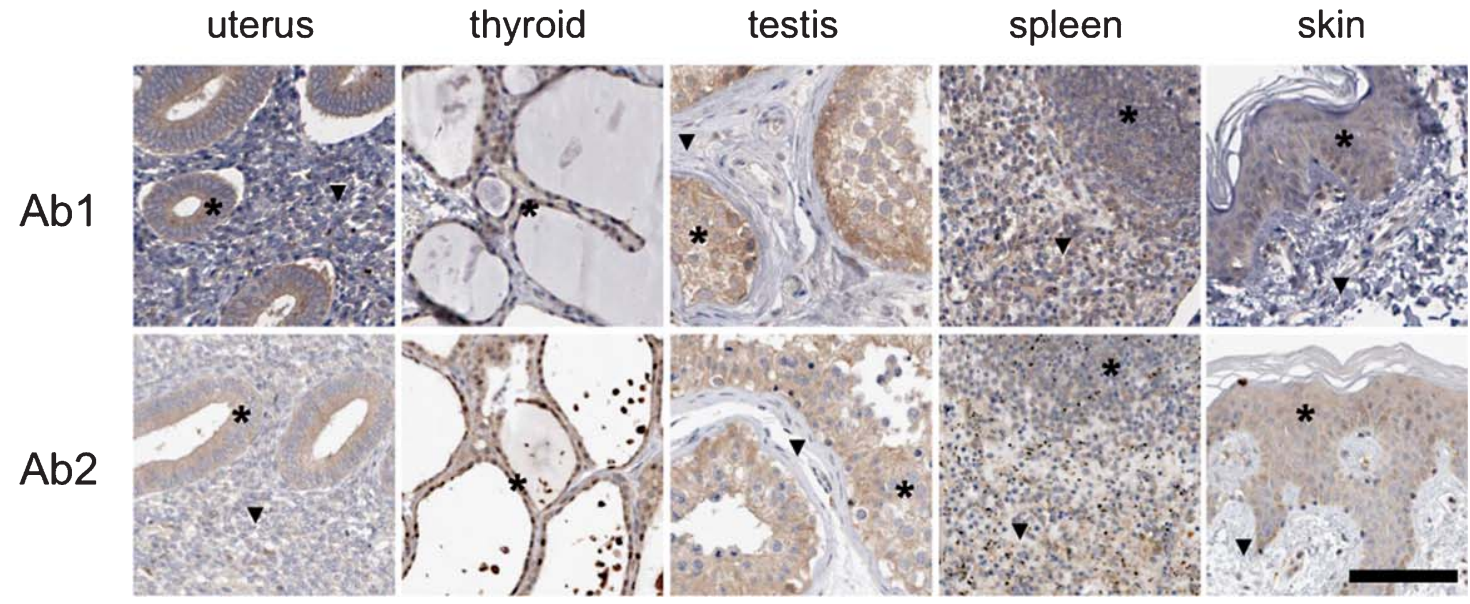

skin

Fig. 1. Huntingtin expression pattern in healthy tissues. Immunohistochemistry using two antibodies directed against huntingtin (Ab1: MAB2166, Ab2: HPA025114). Expression in the cortex (*neurons; $\downarrow$ glial cells), fallopian tube (*glandular cells; $\downarrow$ connective tissue), colon (*glandular cells; $\downarrow$ lamina propria), breast (*glandular cells; $\downarrow$ adipocytes), bone marrow (*hematopoietic cells, $\downarrow$ adipocytes), salivary gland (* glandular cells; $\downarrow$ adipocytes; $\nmid$ secretory acini), pancreas (*ducts; $\downarrow$ islet of langherhans; $\nmid$ acini), lung (*bronchiole; $\downarrow$ connective tissue; $\nmid$ alveoli), kidney (* proximal tubules; $\downarrow$ distal tubules; †glomerulus), heart (*myocytes), uterus (*glandular cells; $\downarrow$ stroma), thyroid $\left({ }^{*}\right.$ glandular cells), testis (*seminiferous ducts; $\downarrow$ connective tissue), spleen (*white pulp; $\downarrow$ red pulp) and skin (*squamous epithelium; $\downarrow$ connective tissue). Scale bar corresponds to $100 \mu \mathrm{m}$. Images adapted from the human protein atlas website, version 11.0. 
HTT and the anterograde motor kinesin-1 and as a consequence, anterograde transport; HTT thereby acts as a molecular switch determining whether transport is anterograde or retrograde [61].

Endocytosis also appears to be an HTT-mediated process. One of the first identified HTT interactors was huntingtin-interacting protein 1 (HIP1). HIP1 participates in clathrin-mediated endocytosis by supporting membrane invagination and the assembly of the clathrin coating [62-65]. Both HTT and HIP1 interact with AP-2; HTT may modulate the assembly of HIP1 with AP-2 and clathrin, localizing the complex to the membrane and regulating clathrincoated pit formation. HTT also interacts with and activates the GTPase Rab11 involved in vesicle recycling during endocytosis [66]. HTT localizes Rab11 to the membrane and participates in the GDP-GTP exchange that activates Rab11. The early endosomal trafficking effector, Rab5 GTPase, can form a complex with HTT through HAP40, such that the HTT-HAP40Rab5 complex associates with early endosomes [67]. Interestingly, the HAP40-HTT complex also interacts with the myosin VI linker, optineurin [68]. Thus, the involvement of HTT in endocytosis is consistent with HTT being a crucial link between the microtubule and the actin cytoskeletons. HTT in a HAP40-Optineurin-MyosinVI complex may regulate actin-dependent dynamics, whereas in complex with dynein-dynactin-kinesin it may regulate microtubuledependent transport.

These examples illustrate how the molecular biology of HTT is complex; however, what we know is consistent with HTT functioning as a scaffold protein for molecular complexes involved in a restricted number of functions. Nevertheless, these functions may have consequences for a wide variety of physiological outcomes during both development and the maintenance of adult homeostasis. For instance, through its function as a regulator of microtubule-based dynamics, HTT influences the division of progenitors at the ventricular zone during cortical development [39], the maturation of newly generated neurons during adult hippocampal neurogenesis [40] and ciliogenesis in ependymal cells [60]. Clearly, the challenge for scientists is to determine when and where the HTT complexes function and their relevance to HD pathogenesis. One way to better define the expression of HTT in individual cells could be to generate mouse lines expressing the GFP reporter under the control of the HTT promoter. Alternatively, a GPF could be knocked-in at the HTT locus to express a GFP-fused HTT protein in mouse. These mouse models could then be analyzed using novel histological methods to directly acquire in three dimension entire mouse organs [69]. Such work may well lead to new insights and perspectives on HTT biology.

\section{PHYSIOLOGICAL OUTCOME OF HTT OUTSIDE OF THE NERVOUS SYSTEM}

An indirect argument that HTT also acts outside the nervous system is that HD patients present with peripheral manifestations. These symptoms of HD have been recently reviewed and include: weight loss; endocrine and metabolic dysfunctions; defects in hematopoiesis; skeletal-muscle and testicular atrophy; aberrant immune cell migration; and cardiac dysfunction [70, 71]. Conversely, mutant HTT may have an effect on other pathologies, and indeed, this is the case for cancer. Two studies have showed an overall decreased risk of cancer in patients with $\operatorname{HD}[72,73]$. Although the incidence of cancer is lower among HD patients, the progression may be faster, mutant HTT being an aggravating factor once cancer is initiated [22]. The peripheral abnormalities observed in HD patients were initially thought to be the consequence of nervous system dysfunction, but it is now clear that at least some are caused directly by the expression of mutant HTT in the affected tissues. However, the details of the molecular mechanisms underlying these peripheral symptoms remain unclear. Non-neuronal tissues may be sensitive to the oxidative stress, inflammation, mitochondrial dysfunction, and abnormalities of energy metabolism and gene transcription caused by the presence of mutant HTT [70, 71]. The loss of the normal function of HTT in these tissues may also cause damage. For example, polyQ-induced abnormalities in HER2 endocytosis in breast cancer cells have consequences for their motility and metastatic behavior leading to increased tumorigenesis and metastasis in HD mice [22].

Although HTT is abundant in a number of tissues (Table 1 and Fig. 1), there have been very few investigations of the physiological relevance of HTT outside of the nervous system. In zebrafish, HTT knock-down produces symptoms of cellular iron deficiency, including decreased hemoglobin concentrations in the blood, increased erythroid and ubiquitous transferrin receptor transcript levels and exhausted maternal iron stores in the yolk [74]. The authors suggested that the underlying mechanism may be a deficiency in endocytosis, particularly of iron, thereby limiting the availability of iron resulting in deficient hemoglobin. In agreement, an earlier study in mouse described a phenotype consistent with a defect in iron transport in extraem- 
bryonic tissues lacking HTT [75]. Wild-type HTT has also been reported to be required for correct spermatogenesis: reduced HTT expression in testis results in disorganized seminiferous tubules with fewer spermatocytes and round spermatids [38].

What can we learn about HD pathogenesis from the study of HTT outside the nervous system? Mammals are made up of different cell types, each with specific functions. This specificity is in part the result of the activities of signaling pathways involving molecular complexes that may be ubiquitous or cell-type specific. The physiological and disease outcomes of the activity of a given pathway may also differ from one cell type to another. An example of this is the role of HTT in the balance between cell survival and apoptosis. Mutant HTT induces cell death through apoptotic and non apoptotic pathways in both cellular and HD mouse models [76-79]. Indeed, the histopathology of HD patients is characterized by atrophy of several brain regions, such that brain weight may be reduced by up to $30 \%[1,80,81]$. In contrast, wild-type HTT protects against cell death induced by various stressors including polyQ-HTT, and has anti-apoptotic properties [82-84]. At the molecular level, the anti-apoptotic properties of HTT may be related to its function as a positive regulator of genes involved in neuronal maintenance [85]. HTT also stimulates the transport of BDNF, and this is itself an anti-apoptotic/pro-survival mechanism [33]. In clear contrast, the situation is quite different in breast cancer cells where mutant HTT has no effect on apoptosis: indeed, immunolabeling for cleaved caspase- 3 is negative in sections of HD tumors and in cancer cells in culture [22]. However, when cells are cultured in suspension, mutant HTT confers resistance to cell death, a phenotypic feature that is associated with metastasis.

Further evidence that the manifestations of the functions of HTT may differ depending on the cellular context comes from an emerging idea that the protein is a regulator of tissue differentiation. In mouse, fulllength polyQ-HTT interferes with adult hippocampal neurogenesis leading to a decrease in neuronal differentiation with an overall reduction in the number of new mature neurons in the dentate gyrus [86]. In fact, wild-type HTT influences adult and embryonic neuronal differentiation. Inactivation of HTT in cortical progenitors favors their neuronal differentiation at the expense of their proliferation [39]. In mature adult hippocampal neurons, loss of HTT affects the dendritic arborization of newly generated neurons [87]. Furthermore, the function of HTT in adult neurogenesis is regulated by its phosphorylation status [40].
There is no information available about the influence of HTT on the differentiation of non neuronal tissues in mouse. Nevertheless, in mouse models of HD and cancer, expression of polyQ-HTT in mammary tumor cells changes their cell fate, and makes them more prone to adopt a mesenchymal phenotype [22].

From this diverse evidence, it seems likely that HTT is a key regulator of the balance between cell differentiation, survival and death, and that the physiological outcomes differ according to the cell type and the cell context. By studying HTT outside the nervous system, we may thus learn from the similarities and differences in its functions in the various tissues in which it is expressed. This will undoubtedly change our understanding of HD.

\section{CONCLUSION}

There is an urgent need for effective treatments for HD that will either slow down or halt the progression of neuronal dysfunction and degeneration. The development of such therapies is based on a sound understanding of the etiology and pathogenesis of this disease. HD is a dominant disorder, but there is evidence that loss of the normal functions of wild-type HTT could act concomitantly and synergistically with the gain of new toxic functions of polyQ-HTT. In fact, the situation is more complex than that. Loss of function of HTT could be a dominant mechanism; this is the case for intracellular transport [33]. Furthermore, HD patients express not only one copy of the mutant huntingtin, but also half the amount of the wild-type protein. A deep knowledge of HTT function is a required step to learn about HD. In particular, knowledge of HTT biology in peripheral tissue might be used to identify biomarkers for disease progression and for readout of treatment efficacy. The HD scientific community should thus be involved in basic studies looking precisely at the spatial and temporal distribution of HTT, and describing the relevance of HTT function where and when it is expressed. Finally, deciphering how mutant HTT acts in other pathological situations like cancer and cardiovascular disease, would also help to better understand the complex biology of HTT and its mutation.

\section{ACKNOWLEDGEMENTS}

We are grateful to F. Saudou for discussions. The laboratory is funded by grants from Agence Nationale pour la Recherche (ANR), Association pour 
la Recherche sur le Cancer (ARC), Fondation pour la Recherche Médicale (FRM). S.H. is a INSERM investigator. C.M.S. was supported by a Fundação para a Ciência e a Tecnologia (FCT, Portugal) doctoral fellowship (SFRH/BD/60728/2009).

\section{CONFLICT OF INTEREST}

The authors declare no conflict of interest.

\section{REFERENCES}

[1] Vonsattel JP, DiFiglia M. Huntington disease. J Neuropathol Exp Neurol. 1998;57:369-84.

[2] Group THsDCR. A novel gene containing a trinucleotide repeat that is expanded and unstable on Huntington's disease chromosomes. The Huntington's Disease Collaborative Research Group. Cell. 1993;72:971-83.

[3] Nance MA, Myers RH. Juvenile onset Huntington's diseaseclinical and research perspectives. Ment Retard Dev Disabil Res Rev. 2001;7:153-7.

[4] Li SH, Schilling G, Young WSd, Li XJ, Margolis RL, Stine OC, Wagster MV, Abbott MH, Franz ML, Ranen NG, Folstein SE, Hedreen JC, Ross CA. Huntington's disease gene (IT15) is widely expressed in human and rat tissues. Neuron. 1993;11:985-93.

[5] Strong TV, Tagle DA, Valdes JM, Elmer LW, Boehm K, Swaroop M, Kaatz KW, Collins FS, Albin RL. Widespread expression of the human and rat Huntington's disease gene in brain and nonneural tissues. Nat Genet. 1993;5:259-65.

[6] Trottier Y, Devys D, Imbert G, Saudou F, An I, Lutz Y, Weber C, Agid Y, Hirsch EC, Mandel JL. Cellular localization of the Huntington's disease protein and discrimination of the normal and mutated form. Nat Genet. 1995;10:104-10.

[7] Sharp AH, Loev SJ, Schilling G, Li SH, Li XJ, Bao J, Wagster MV, Kotzuk JA, Steiner JP, Lo A, Hedreen J, Sisodia S, Snyder SH, Dawson TM, Ryugo DK, Ross CA. Widespread expression of Huntington's disease gene (IT15) protein product. Neuron. 1995;14:1065-74.

[8] Van Raamsdonk JM, Murphy Z, Selva DM, Hamidizadeh R, Pearson J, Petersen A, Bjorkqvist M, Muir C, Mackenzie IR, Hammond GL, Vogl AW, Hayden MR, Leavitt BR. Testicular degeneration in Huntington disease. Neurobiol Dis. 2007;26:512-20.

[9] Bjorkqvist M, Wild EJ, Thiele J, Silvestroni A, Andre R, Lahiri N, Raibon E, Lee RV, Benn CL, Soulet D, Magnusson A, Woodman B, Landles C, Pouladi MA, Hayden MR, Khalili-Shirazi A, Lowdell MW, Brundin P, Bates GP, Leavitt BR, Moller T, Tabrizi SJ. A novel pathogenic pathway of immune activation detectable before clinical onset in Huntington's disease. J Exp Med. 2008;205:1869-77.

[10] Toneff T, Mende-Mueller L, Wu Y, Hwang SR, Bundey R, Thompson LM, Chesselet MF, Hook V. Comparison of huntingtin proteolytic fragments in human lymphoblast cell lines and human brain. J Neurochem. 2002;82:84-92

[11] Maglione V, Cannella M, Gradini R, Cislaghi G, Squitieri F. Huntingtin fragmentation and increased caspase 3,8 and 9 activities in lymphoblasts with heterozygous and homozygous Huntington's disease mutation. Mech Ageing Dev. 2006; 127:213-6.

[12] Hoogeveen AT, Willemsen R, Meyer N, de Rooij KE, Roos RA, van Ommen GJ, Galjaard H. Characterization and local- ization of the Huntington disease gene product. Hum Mol Genet. 1993;2:2069-73.

[13] Sawa A, Wiegand GW, Cooper J, Margolis RL, Sharp AH, Lawler JF, Jr, Greenamyre JT, Snyder SH, Ross CA. Increased apoptosis of Huntington disease lymphoblasts associated with repeat length-dependent mitochondrial depolarization. Nat Med. 1999;5:1194-8.

[14] Gutekunst CA, Levey AI, Heilman CJ, Whaley WL, Yi H, Nash NR, Rees HD, Madden JJ, Hersch SM. Identification and localization of huntingtin in brain and human lymphoblastoid cell lines with anti-fusion protein antibodies. Proc Natl Acad Sci U S A. 1995;92:8710-4.

[15] Schilling G, Sharp AH, Loev SJ, Wagster MV, Li SH, Stine OC, Ross CA. Expression of the Huntington's disease (IT15) protein product in HD patients. Hum Mol Genet. 1995;4:1365-71.

[16] Ciammola A, Sassone J, Alberti L, Meola G, Mancinelli E, Russo MA, Squitieri F, Silani V. Increased apoptosis, Huntingtin inclusions and altered differentiation in muscle cell cultures from Huntington's disease subjects. Cell Death Differ. 2006;13:2068-78.

[17] De Rooij KE, Dorsman JC, Smoor MA, Den Dunnen JT, Van Ommen GJ. Subcellular localization of the Huntington's disease gene product in cell lines by immunofluorescence and biochemical subcellular fractionation. Hum Mol Genet. 1996;5:1093-9.

[18] Schmitt I, Bachner D, Megow D, Henklein P, Hameister H, Epplen JT, Riess O. Expression of the Huntington disease gene in rodents: Cloning the rat homologue and evidence for downregulation in non-neuronal tissues during development. Hum Mol Genet. 1995;4:1173-82.

[19] Casanova E, Alonso-Llamazares A, Zamanillo D, Garate C, Calvo P, Chinchetru MA. Identification of a long huntingtin mRNA transcript in mouse brain. Brain Res. 1996;743:320-3.

[20] Metzler M, Helgason CD, Dragatsis I, Zhang T, Gan L, Pineault N, Zeitlin SO, Humphries RK, Hayden MR. Huntingtin is required for normal hematopoiesis. Hum Mol Genet. 2000;9:387-94.

[21] Wood JD, MacMillan JC, Harper PS, Lowenstein PR, Jones AL. Partial characterisation of murine huntingtin and apparent variations in the subcellular localisation of huntingtin in human, mouse and rat brain. Hum Mol Genet. 1996;5: 481-7.

[22] Moreira Sousa C, McGuire JR, Thion MS, Gentien D, de la Grange P, Tezenas du Montcel S, Vincent-Salomon A, Durr A, Humbert $S$. The Huntington disease protein accelerates breast tumour development and metastasis through ErbB2/HER2 signalling. EMBO Mol Med. 2013;5:309-25.

[23] Bjorkqvist M, Fex M, Renstrom E, Wierup N, Petersen A, Gil J, Bacos K, Popovic N, Li JY, Sundler F, Brundin P, Mulder H. The R6/2 transgenic mouse model of Huntington's disease develops diabetes due to deficient beta-cell mass and exocytosis. Hum Mol Genet. 2005;14:565-74.

[24] Sathasivam K, Hobbs C, Turmaine M, Mangiarini L, Mahal A, Bertaux F, Wanker EE, Doherty P, Davies SW, Bates GP. Formation of polyglutamine inclusions in non-CNS tissue. Hum Mol Genet. 1999;8:813-22.

[25] Moffitt H, McPhail GD, Woodman B, Hobbs C, Bates GP. Formation of polyglutamine inclusions in a wide range of non-CNS tissues in the HdhQ150 knock-in mouse model of Huntington's disease. PLoS One. 2009;4:e8025.

[26] Mihm MJ, Amann DM, Schanbacher BL, Altschuld RA, Bauer JA, Hoyt KR. Cardiac dysfunction in the R6/2 mouse model of Huntington's disease. Neurobiol Dis. 2007; 25:297308 
[27] Ponten F, Jirstrom K, Uhlen M. The Human Protein Atlas-a tool for pathology. J Pathol. 2008;216:387-93.

[28] Lo Sardo V, Zuccato C, Gaudenzi G, Vitali B, Ramos C, Tartari M, Myre MA, Walker JA, Pistocchi A, Conti L, Valenza M, Drung B, Schmidt B, Gusella J, Zeitlin S, Cotelli F, Cattaneo E. An evolutionary recent neuroepithelial cell adhesion function of huntingtin implicates ADAM10-Ncadherin. Nat Neurosci. 2012;15:713-21.

[29] Strehlow AN, Li JZ, Myers RM. Wild-type huntingtin participates in protein trafficking between the Golgi and the extracellular space. Hum Mol Genet. 2007;16:391-409.

[30] Anne SL, Saudou F, Humbert S. Phosphorylation of huntingtin by cyclin-dependent kinase 5 is induced by DNA damage and regulates wild-type and mutant huntingtin toxicity in neurons. J Neurosci. 2007;27:7318-28.

[31] Harjes P, Wanker EE. The hunt for huntingtin function: Interaction partners tell many different stories. Trends Biochem Sci. 2003;28:425-33.

[32] DiFiglia M, Sapp E, Chase K, Schwarz C, Meloni A, Young C, Martin E, Vonsattel JP, Carraway R, Reeves SA, Boyce FM, Aronin N. Huntingtin is a cytoplasmic protein associated with vesicles in human and rat brain neurons. Neuron. 1995; 14:1075-81.

[33] Gauthier LR, Charrin BC, Borrell-Pages M, Dompierre JP, Rangone H, Cordelieres FP, De Mey J, MacDonald ME, Lessmann V, Humbert S, Saudou F. Huntingtin controls neurotrophic support and survival of neurons by enhancing BDNF vesicular transport along microtubules. Cell. 2004;118:12738.

[34] Hoffner G, Kahlem P, Djian P. Perinuclear localization of huntingtin as a consequence of its binding to microtubules through an interaction with beta-tubulin: Relevance to Huntington's disease. J Cell Sci. 2002;115:941-8.

[35] Duyao MP, Auerbach AB, Ryan A, Persichetti F, Barnes GT, McNeil SM, Ge P, Vonsattel JP, Gusella JF, Joyner AL, MacDonald ME. Inactivation of the mouse Huntington's disease gene homolog Hdh. Science. 1995;269:407-10.

[36] Nasir J, Floresco SB, O'Kusky JR, Diewert VM, Richman JM, Zeisler J, Borowski A, Marth JD, Phillips AG, Hayden MR. Targeted disruption of the Huntington's disease gene results in embryonic lethality and behavioral and morphological changes in heterozygotes. Cell. 1995;81:811-23.

[37] Zeitlin S, Liu JP, Chapman DL, Papaioannou VE, Efstratiadis A. Increased apoptosis and early embryonic lethality in mice nullizygous for the Huntington's disease gene homologue. Nat Genet. 1995;11:155-63.

[38] Dragatsis I, Levine MS, Zeitlin S. Inactivation of hdh in the brain and testis results in progressive neurodegeneration and sterility in mice. Nat Genet. 2000;26:300-6.

[39] Godin JD, Colombo K, Molina-Calavita M, Keryer G, Zala D, Charrin BC, Dietrich P, Volvert ML, Guillemot F, Dragatsis I, Bellaiche Y, Saudou F, Nguyen L, Humbert S. Huntingtin is required for mitotic spindle orientation and mammalian neurogenesis. Neuron. 2010;67:392-406.

[40] Ben M'barek K, Pla P, Orvoen S, Benstaali C, Godin JD, Gardier AM, Saudou F, David DJ, Humbert S. Huntingtin mediates anxiety/depression-related behaviors and hippocampal neurogenesis. J Neurosci. 2013;33:8608-20.

[41] Zhang S, Feany MB, Saraswati S, Littleton JT, Perrimon N. Inactivation of Drosophila Huntingtin affects long-term adult functioning and the pathogenesis of a Huntington's disease model. Dis Model Mech. 2009;2:247-66.

[42] Truant R, Atwal RS, Burtnik A. Nucleocytoplasmic trafficking and transcription effects of huntingtin in Huntington's disease. Prog Neurobiol. 2007;83:211-27.
[43] Desmond CR, Atwal RS, Xia J, Truant R. Identification of a karyopherin beta1/beta2 proline-tyrosine nuclear localization signal in huntingtin protein. J Biol Chem. 2012;287: 39626-33.

[44] Xia J, Lee DH, Taylor J, Vandelft M, Truant R. Huntingtin contains a highly conserved nuclear export signal. Hum Mol Genet. 2003;12:1393-403.

[45] Gerber HP, Seipel K, Georgiev O, Hofferer M, Hug M, Rusconi S, Schaffner W. Transcriptional activation modulated by homopolymeric glutamine and proline stretches. Science. 1994;263:808-11.

[46] Perutz MF. Glutamine repeats as polar zippers: Their role in inherited neurodegenerative disease. Molecular Medicine. 1995;1:718-21.

[47] Steffan JS, Kazantsev A, Spasic-Boskovic O, Greenwald M, Zhu YZ, Gohler H, Wanker EE, Bates GP, Housman DE, Thompson LM. The Huntington's disease protein interacts with p53 and CREB-binding protein and represses transcription. Proc Natl Acad Sci U S A. 2000;97:6763-8.

[48] Li SH, Cheng AL, Zhou H, Lam S, Rao M, Li H, Li XJ. Interaction of huntington disease protein with transcriptional activator sp1. Mol Cell Biol. 2002;22:1277-87.

[49] Takano H, Gusella JF. The predominantly HEAT-like motif structure of huntingtin and its association and coincident nuclear entry with dorsal, an NF-kB/Rel/dorsal family transcription factor. BMC Neurosci. 2002;3:15.

[50] Yohrling GJ, Farrell LA, Hollenberg AN, Cha JH. Mutant huntingtin increases nuclear corepressor function and enhances ligand-dependent nuclear hormone receptor activation. Mol Cell Neurosci. 2003;23:28-38.

[51] Zuccato C, Tartari M, Crotti A, Goffredo D, Valenza M, Conti L, Cataudella T, Leavitt BR, Hayden MR, Timmusk T, Rigamonti D, Cattaneo E. Huntingtin interacts with REST/NRSF to modulate the transcription of NRSE-controlled neuronal genes. Nat Genet. 2003;35:76-83.

[52] Kegel KB, Meloni AR, Yi Y, Kim YJ, Doyle E, Cuiffo BG, Sapp E, Wang Y, Qin ZH, Chen JD, Nevins JR, Aronin $\mathrm{N}$, DiFiglia M. Huntingtin is present in the nucleus, interacts with the transcriptional corepressor C-terminal binding protein, and represses transcription. J Biol Chem. 2002;277: 7466-76.

[53] Bae BI, Xu H, Igarashi S, Fujimuro M, Agrawal N, Taya Y, Hayward SD, Moran TH, Montell C, Ross CA, Snyder SH, Sawa A. p53 Mediates Cellular Dysfunction and Behavioral Abnormalities in Huntington's Disease. Neuron. 2005;47:2941.

[54] Li XJ, Li SH, Sharp AH, Nucifora FC Jr, Schilling G, Lanahan A, Worley P, Snyder SH, Ross CA. A huntingtin-associated protein enriched in brain with implications for pathology. Nature. 1995;378:398-402.

[55] McGuire JR, Rong J, Li SH, Li XJ. Interaction of Huntingtin-associated protein-1 with kinesin light chain: Implications in intracellular trafficking in neurons. J Biol Chem. 2006;281:3552-9.

[56] Li SH, Gutekunst CA, Hersch SM, Li XJ. Interaction of huntingtin-associated protein with dynactin P150Glued. J Neurosci. 1998;18:1261-9.

[57] Caviston JP, Ross JL, Antony SM, Tokito M, Holzbaur EL. Huntingtin facilitates dynein/dynactin-mediated vesicle transport. Proc Natl Acad Sci U S A. 2007;104:10045-50.

[58] Gunawardena S, Her LS, Brusch RG, Laymon RA, Niesman IR, Gordesky-Gold B, Sintasath L, Bonini NM, Goldstein LS. Disruption of axonal transport by loss of huntingtin or expression of pathogenic polyQ proteins in Drosophila. Neuron. 2003;40:25-40 
[59] Liot G, Zala D, Pla P, Mottet G, Piel M, Saudou F. Mutant Huntingtin alters retrograde transport of TrkB receptors in striatal dendrites. J Neurosci. 2013;33:6298-309.

[60] Keryer G, Pineda JR, Liot G, Kim J, Dietrich P, Benstaali C, Smith K, Cordelieres FP, Spassky N, Ferrante RJ, Dragatsis I, Saudou F. Ciliogenesis is regulated by a huntingtin-HAP1PCM1 pathway and is altered in Huntington disease. $\mathrm{J}$ Clin Invest. 2011;121:4372-82.

[61] Colin E, Zala D, Liot G, Rangone H, Borrell-Pages M, Li XJ, Saudou F, Humbert S. Huntingtin phosphorylation acts as a molecular switch for anterograde/retrograde transport in neurons. EMBO J. 2008;27:2124-34.

[62] Waelter S, Scherzinger E, Hasenbank R, Nordhoff E, Lurz R, Goehler H, Gauss C, Sathasivam K, Bates GP, Lehrach $\mathrm{H}$, Wanker EE. The huntingtin interacting protein HIP1 is a clathrin and alpha-adaptin- binding protein involved in receptor-mediated endocytosis. Hum Mol Genet. 2001;10:1807-17.

[63] Engqvist-Goldstein AE, Warren RA, Kessels MM, Keen JH, Heuser J, Drubin DG. The actin-binding protein Hip1R associates with clathrin during early stages of endocytosis and promotes clathrin assembly in vitro. J Cell Biol. 2001;154:1209-23.

[64] Wanker EE, Rovira C, Scherzinger E, Hasenbank R, Walter S, Tait D, Colicelli J, Lehrach H. HIP-I: A huntingtin interacting protein isolated by the yeast two-hybrid system. Hum Mol Genet. 1997;6:487-95.

[65] Kalchman MA, Koide HB, McCutcheon K, Graham RK, Nichol K, Nishiyama K, Kazemi-Esfarjani P, Lynn FC, Wellington C, Metzler M, Goldberg YP, Kanazawa I, Gietz RD, Hayden MR. HIP1, a human homologue of S. cerevisiae Sla2p, interacts with membrane-associated huntingtin in the brain. Nat Genet. 1997; 16:44-53.

[66] Li X, Sapp E, Valencia A, Kegel KB, Qin ZH, Alexander J, Masso N, Reeves P, Ritch JJ, Zeitlin S, Aronin N, Difiglia M. A function of huntingtin in guanine nucleotide exchange on Rab11. Neuroreport. 2008;19:1643-7.

[67] Pal A, Severin F, Lommer B, Shevchenko A, Zerial M. Huntingtin-HAP40 complex is a novel Rab5 effector that regulates early endosome motility and is up-regulated in Huntington's disease. J Cell Biol. 2006;172:605-18.

[68] Faber PW, Barnes GT, Srinidhi J, Chen J, Gusella JF, MacDonald ME. Huntingtin interacts with a family of WW domain proteins. Hum Mol Genet. 1998;7:1463-74.

[69] Chung K, Deisseroth K. CLARITY for mapping the nervous system. Nat Methods. 2013;10:508-13.

[70] Sassone J, Colciago C, Cislaghi G, Silani V, Ciammola A. Huntington's disease: The current state of research with peripheral tissues. Exp Neurol. 2009;219:385-97.

[71] van der Burg JM, Bjorkqvist M, Brundin P. Beyond the brain: Widespread pathology in Huntington's disease. Lancet Neurol. 2009;8:765-74.

[72] Ji J, Sundquist K, Sundquist J. Cancer incidence in patients with polyglutamine diseases: A population-based study in Sweden. Lancet Oncol. 2012;13:642-8.

[73] Sorensen SA, Fenger K, Olsen JH. Significantly lower incidence of cancer among patients with Huntington disease: An apoptotic effect of an expanded polyglutamine tract? Cancer. 1999;86:1342-6.

[74] Lumsden AL, Henshall TL, Dayan S, Lardelli MT, Richards RI. Huntingtin-deficient zebrafish exhibit defects in iron utilization and development. Hum Mol Genet. 2007;16:190520.

[75] Dragatsis I, Efstratiadis A, Zeitlin S. Mouse mutant embryos lacking huntingtin are rescued from lethality by wild-type extraembryonic tissues. Development. 1998;125:1529-39.

[76] Gray M, Shirasaki DI, Cepeda C, Andre VM, Wilburn B, Lu XH, Tao J, Yamazaki I, Li SH, Sun YE, Li XJ, Levine MS, Yang XW. Full-length human mutant huntingtin with a stable polyglutamine repeat can elicit progressive and selective neuropathogenesis in BACHD mice. J Neurosci. 2008;28:6182-95.

[77] Reddy PH, Charles V, Williams M, Miller G, Whetsell WO, Jr, Tagle DA. Transgenic mice expressing mutated full-length HD cDNA: A paradigm for locomotor changes and selective neuronal loss in Huntington's disease. Philos Trans R Soc Lond B Biol Sci. 1999;354:1035-45.

[78] Hackam AS, Yassa AS, Singaraja R, Metzler M, Gutekunst CA, Gan L, Warby S, Wellington CL, Vaillancourt J, Chen N, Gervais FG, Raymond L, Nicholson DW, Hayden MR. Huntingtin interacting protein 1 (HIP-1) induces apoptosis via a novel caspase-dependent death effector domain. J Biol Chem. 2000;275:41299-41308.

[79] Dragunow M, Faull RL, Lawlor P, Beilharz EJ, Singleton $\mathrm{K}$, Walker EB, Mee E. In situ evidence for DNA fragmentation in Huntington's disease striatum and Alzheimer's disease temporal lobes. Neuroreport. 1995;6:1053-7.

[80] Aylward EH, Anderson NB, Bylsma FW, Wagster MV, Barta PE, Sherr M, Feeney J, Davis A, Rosenblatt A, Pearlson GD, Ross CA. Frontal Lobe Volume In Patients With HuntingtonsDisease. Neurology. 1998;50:252-258.

[81] Rosas HD, Liu AK, Hersch S, Glessner M, Ferrante RJ, Salat DH, van der Kouwe A, Jenkins BG, Dale AM, Fischl B. Regional and progressive thinning of the cortical ribbon in Huntington's disease. Neurology. 2002;58:695-701.

[82] Rigamonti D, Bauer JH, De-Fraja C, Conti L, Sipione S, Sciorati C, Clementi E, Hackam A, Hayden MR, Li Y, Cooper JK, Ross CA, Govoni S, Vincenz C, Cattaneo E. Wild-type huntingtin protects from apoptosis upstream of caspase-3. J Neurosci. 2000;20:3705-13.

[83] Rigamonti D, Sipione S, Goffredo D, Zuccato C, Fossale E, Cattaneo E. Huntingtin's neuroprotective activity occurs via inhibition of procaspase- 9 processing. J Biol Chem. 2001;276:14545-8.

[84] Leavitt BR, Raamsdonk JM, Shehadeh J, Fernandes H, Murphy Z, Graham RK, Wellington CL, Raymond LA, Hayden MR. Wild-type huntingtin protects neurons from excitotoxicity. J Neurochem. 2006;96:1121-9.

[85] Zuccato C, Ciammola A, Rigamonti D, Leavitt BR, Goffredo D, Conti L, MacDonald ME, Friedlander RM, Silani V, Hayden MR, Timmusk T, Sipione S, Cattaneo E. Loss of huntingtin-mediated BDNF gene transcription in Huntington's disease. Science. 2001;293:493-8.

[86] Simpson JM, Gil-Mohapel J, Pouladi MA, Ghilan M, Xie Y, Hayden MR, Christie BR. Altered adult hippocampal neurogenesis in the YAC128 transgenic mouse model of Huntington disease. Neurobiol Dis. 2011;41:249-60.

[87] Pla P, Orvoen S, Benstaali C, Dodier S, Gardier AM, David DJ, Humbert S, Saudou F. Huntingtin acts non cell-autonomously on hippocampal neurogenesis and controls anxiety-related behaviors in adult mouse. PLoS One. 2013;8:e73902. 